It is plain that Canada, in spite of its fine schools, universities, and public libraries, has not yet realised the educational value of museums, a value that has only recently been admitted in Great Britain. There are indeed some school museums, but most of them are neglected and bear no more relation to the curriculum than with us. In nearly half the museums, some instruction is given to school classes, but there is no true co-operation with the educational authorities. Thirty museums lend specimens to schools and a few are really active in this direction. These are hopeful signs and one can scarcely doubt that the lead of the United States will before long be followed.

Looking at the state of affairs still more broadly, the authors find an absence of co-operation. Were this need supplied, the few really good museums could do much to raise the general level. Towards future progress the criticisms and suggestions of this most valuable report cannot fail to be an inspiration and a guide.

\title{
Obituary
}

\section{Dr. ERnest Clarke}

$\mathrm{E}$ RNEST CLARKE was a well-known London eye-specialist. Born in Hampstead on July 21,1857 , he died on November 22, 1932. His career is well described in the medical journals of December 3. Educated at University College School, he joined St. Bartholomew's Hospital Medical School in 1876. He began his career in 1880 , as a general practitioner at Blackheath but soon turned to ophthalmic work and moved to Chandos Street, W. He was very successful, through making the correction of small errors of refraction his special care.

A linguist, a traveller, a musician specially devoted to the organ, an enthusiastic collector, a keen freemason, gifted with a cultivated mind, both artistic and scientific, Clarke was a most engaging personality. Happy in his success, he enjoyed good health until recent years, when he suffered much as a result of some infection, I believe, but was stoically cheerful and active to the last. A member of the Royal Institution since 1896, he was a constant attendant and one of its most valued helpers.

I knew him in his student days, as an alert member of my First M.B., University of London tutorial class, at St. Bartholomew's Hospital. No small part of my organic chemistry (1874) was ingested into him; how much he eventually digested I will not say. Among medical men he has always appealed to me by the clearness of his scientific outlook and entire absence of pose. It is interesting to compare training such as he had with the present. Except anatomy, no preliminary subject was then taught practically. A beginning had been made, in physiology, at University College and we know that Michael Foster introduced the subject at Cambridge in 1876 ; yet Lauder Brunton and I, already in 1868-69, had attended a wonderful lecture course by Ludwig, in Leipzig, which was minutely experimental from beginning to end and, as a consequence, unforgettable. Idealists have made such teaching impossible here to-day.

H. E. A.

\section{DR. J. J. CARTY}

DR. J. J. CARTY, for many years connected with the Bell Telephone System in America, died on December 27 at the age of serenty-one. $\mathrm{He}$ had retired from active service in 1930. Carty played a great part in the development of electrical communication, and was probably as instrumental as any one man in the creation of the present-day American telephone system, which involves some twenty million stations and eighty million miles of wires.

Carty was appointed chief engineer of the New York Telephone Company at a time when the problem of placing exchange wires underground was pressing for a solution, and he guided the successful development of the lead-covered paperinsulated cable. Later he became chief engineer of the American Telephone and Telegraph Company, and in this capacity he carried through to successful conclusion the building of the first transcontinental telephone lines in 1914-15, including the adaptation of the vacuum tube amplifier to the telephone repeater. Later in the same year he was able to announce the bridging of the Atlantic Ocean by radio telephone. He was also instrumental in the development of lead-covered cables for long distance telephony, the first undertaking of this kind being the Boston-Washington toll cable of large gauge wire which was placed in operation in 1913. This was followed by the New York-Chicago toll cable, the first to use small gauge wire, in 1921.

Dr. Carty was a member of the National Research Council of America, and a member of council of the National Academy of Sciences of the United States. In 1915 he was elected president of the American Institute of Electrical Engineers. In 1903 he was awarded the Longstreth medal and, in 1916, the Franklin medal of the Franklin Institute; and in 1918, the Edison medal of the American Institute of Electrical Engineers.

To those who worked for him, Dr. Carty will be as much remembered for his inspiring leadership as for his deep knowledge of electrical communication.

\section{Prof. A. M. Stalker}

Alexander Mrtcherl Stalker, who died in Dundee on December 23, was born in Leven in 1853. After an arts course from which he graduated with first-class honours in mental philosophy, he entered on the study of medicine and after graduating at Edinburgh he studied also at Leipzig. 
Ultimately he started practice in Dundee, where he was soon appointed physician to the Royal Infirmary. Distinguished not only by his clinical skill but also by his wide philosophic outlook, he became a leader in a group of younger men who were raising medicine in Dundee to the academic standard that fitted it, when the time was ripe, to furnish the Medical School of the University of St. Andrews.

In 1898 Stalker was with universal approval appointed the first professor of medicine in the new School and grasped whole-heartedly the opportunities afforded of service to medical education in the training of his students. His aim throughout was to lay clearly the main lines on which medical knowledge could be interpreted and applied. In this he was singularly successful, while at the same time he imbued his pupils with an enthusiastic curiosity that encouraged them to track to its place anything which they might encounter outside the range of their previous experience.

Prof. Stalker was endowed with an unusual memory and, widely read, not only in philosophy but also in general history and literature, he was able by accurate reference to keep medicine in touch with the general body of knowledge. Though a good writer and a fine lecturer, his publications were limited to occasional papers, in the interests of his routine duties as physician and teacher. In 1924, when he retired, the University in recognition of his services conferred on him the degree of LL.D.

\section{Mr. G. R. CARLINE}

George Reginald Carline, who died in London on December 24 at the age of forty-seven years, succeeded the late H. Ling Roth as keeper of the Banksfield Museum, Halifax, in 1924. He continued the work of his predecessor in adding to the collections of the Museum illustrating the development of the primitive loom and weaving technique. Formerly he had been assistant curator to the
Wellcome Historical Medical Museum, London, and afterwards at the Pitt-Rivers Museum, Oxford. In 1929 he accompanied the British Association to South Africa, contributing to the proceedings of Section H (Anthropology) a paper on the handloom in Africa, and afterwards spending some time in observation among the Mambwe tribe of Northern Rhodesia. He had excavated with Sir Flinders Petrie in the Fayum in 1925 and was closely associated with the work of the Folk-Lore Society and the Royal Anthropological Institute, and was a contributor to their journals.

WE regret to announce the following deaths:

Mr. Cecil Fowler Beadles, curator of the Pathological Department of the Museum of the Royal College of Surgeons, on January 3, aged sixty-six years.

Prof. Robert Donaldson, Sir William Dunn professor of pathology in the University of London, on January 3, aged fifty-five years.

Dr. Malcolm Evan MacGregor, director of the Wellcome Entomological Field Laboratory, of the Wellcome Research Institution, who has done much work in connexion with malaria, on January 12, aged forty-three years.

Mr. J. L. S. Hatton, Vice-Chancellor of the University of London, and first principal of East London College, on January 13, aged sixty-seven years.

Sir Robert Jones, K.B.E., president of the Association of Surgeons of Great Britain and, in 1921-25, president of the British Orthopædic Association, on January 14, aged seventy-four years.

Mr. Basil H. Soulsby, formerly librarian of the British Museum (Natural History), on January 14, aged sixty-eight years.

Prof. C. M. Thompson, emeritus professor of chemistry in the University College of South Wales and Monmouthshire, on January 4, aged seventy-seven years.

\section{News and Views}

\section{Sir Edward Sharpey-Schafer, F.R.S.}

Sir Edward Sharpey-Schafer, who will retire from the chair of physiology in the University of Edinburgh at the end of next September, went to Edinburgh in 1899 from the Jodrell chair of physiology in University College, London. He has administered an important department and lectured to large classes of medical students, but he has also had abundant energy left to devote to his numerous investigations, which have extended over a wide field including general histology, the endocrine organs, the nervous system, the pulmonary circulation and artificial respiration. His published books include his masterly work on the endocrine organs and his well-known "Essentials of Histology", which has passed through seven editions since its author went to Edinburgh. The feature of Sir Edward's work in the University of Edinburgh has been his emphasis on, and his encouragement of, research. In his eightythird year, he is still active and acute in mind, and as keen and assiduous as ever in the prosecution of research. His retirement from the chair will remove one of the best-known figures in the University Medical School and the senior member of the Faculty of Medicine.

Appreciative reference should also be made to Sir Edward's services, outside his University duties, for example, as founder in 1908 of the Quarterly Journal of Experimental Physiology, which he has edited throughout its existence, and to his continued interest in the Physiological Society, of which he is now 